\title{
Wrodzone zaburzenia czynności płytek krwi
}

\author{
Inherited platelet function disorders
}

\author{
Krzysztof Chojnowski \\ Zakład Zaburzeń Hemostazy, Uniwersytet Medyczny, Łódź
}

\begin{abstract}
Streszczenie
Wrodzone zaburzenia czynności plytek krwi (IPFD) stanowia duża grupe bardzo rzadko wystepujacych skaz krwotocznych. Sa one zróżnicowane pod względem rodzaju defektu ptytek, sposobu dziedziczenia i przebiegu klinicznego. Moga sie wiazać z defektami glikoprotein btony ptytkowej prowadzacymi do upośledzenia adhezji (zespót Bernarda-Souliera) lub agregacji plytek (trombastenia Glanzmanna), anomaliami receptorów dla rozpuszczalnych agonistów (defekty receptora dla ADP, dla tromboksanu $A_{2}$ ), zaburzeniami ziarnistości plytkowych alfa (zespót szarych ptytek, skaza plytkowa Quebec) i gestych (izolowany defekt, zespót Hermansky'ego-Pudlaka, zespól Chediaka-Higashiego), anomaliami dróg przekazywania sygnatu (zespót Ghosal) $i$ zaburzeniami prokoagulacyjnej aktywności plytek (zespót Scotta, zespót Stormorken). Niektóre z IPFD moga przebiegać z matoptytkowościa, obecnościq olbrzymich plytek $i$ z innymi objawami klinicznymi. $Z$ powodu skomplikowanej diagnostyki większość tagodnych wrodzonych defektów plytek pozostaje nierozpoznana. W pracy przedstawiono klasyfikacje, charakterystyke kliniczna i laboratoryjna oraz zasady leczenia IPFD.
\end{abstract}

Słowa kluczowe: płytki krwi, wrodzone trombocytopatie, krwawienia, diagnostyka, leczenie

Hematologia 2016; 7, 4: 287-294

\begin{abstract}
Inherited platelet function disorders (IPFD) constitute a large group of diseases involving a wide range of genetic defects that can lead to bleeding symptoms of varying severity. They are associated with defects in surface membrane glycoproteins resulting in e.g. Bernard Soulier Syndrome and Glanzmann Thrombasthenia causing defects in platelet adhesion and aggregation, respectively, as well as in receptors for agonists (P2 $\left.Y_{12}\right)$, disrupting platelet signalling. Defects affecting platelet granules can be characterised by abnormalities of alpha-granules as in the Gray platelet syndrome or dense granules as in Hermansky-Pudlak and Chediak-Higashi syndromes. Finally, defects in proteins essential to signalling pathways (Ghosal syndrome) or in platelet-derived procoagulant activity (Scott and Stormorken syndromes) also impair platelet function. In some cases IPFD are associated with thrombocytopenia, giant platelets and various comorbidities. This review summarizes the state of the art of classification, clinical course, lab characteristic and treatment of IPFD.
\end{abstract}

Key words: platelets, inherited thrombocytopathy, bleeding, diagnosis, treatment

Hematologia 2016; 7, 4: 287-294

Adres do korespondencji: Krzysztof Chojnowski, Zakład Zaburzeń Hemostazy, Uniwersytet Medyczny w Łodzi, WSS im. M. Kopernika, ul. Ciołkowskiego 2, 93-510 Łódź, tel. 4268950 58, e-mail: krzycho17@yahoo.com 


\section{Wprowadzenie}

Wrodzone zaburzenia czynności płytek krwi (IPFD, inherited platelet function disorders) należą do bardzo rzadko rozpoznawanych przyczyn skazy krwotocznej. Mogą być związane $z$ anomaliami dotyczącymi receptorów płytkowych, dróg przekazywania sygnału, ziarnistości płytkowych lub fosfolipidów błony płytkowej (tab. 1) [1]. Wrodzone trombocytopatie prowadzą do skazy krwotocznej, której nasilenie zależy od rodzaju defektu. Ciężki przebieg skazy krwotocznej jest charakterystyczny dla trombastenii Glanzmanna (GT, Glanzmann thrombasthenia) i zespołu Bernarda-Souliera (BSS, Bernard-Soulier syndrome). Niebezpieczne dla życia krwawienia mogą wystąpić również u pacjentów $z$ zespołem Scotta i skazą płytkową Quebec. W innych defektach płytkowych skaza krwotoczna jest lagodna, a głównym problemem pozostają krwawienia pourazowe. W niektórych IPFD poza skazą krwotoczną wspólistnieją inne objawy kliniczne tworzące obraz specyficznego zespolu chorobowego. Częstości występowania IPFD w populacji ogólnej dotychczas nie ustalono. Prawdopodobnie występują częściej niż są rozpoznawane, ponieważ ich diagnostyka laboratoryjna jest bardzo trudna, pracochłonna i kosztowna [2]. W ostatnich latach dokonał się znaczny postęp w poznaniu etiopatogenezy IPFD. Stało się to możliwe dzięki wprowadzeniu do diagnostyki metod biologii molekularnej [3].

Tabela 1. Klasyfikacja patogenetyczna wrodzonych trombocytopatii

Table 1. Classification of inherited platelet function disorders

\begin{tabular}{|c|c|c|c|}
\hline Rodzaj defektu & Choroba & Sposób dziedziczenia & Defektywny gen \\
\hline \multirow[t]{4}{*}{$\begin{array}{l}\text { Anomalia receptorów dla białek } \\
\text { adhezyjnych }\end{array}$} & $\begin{array}{l}\text { Płytkowy typ choroby } \\
\text { von Willebranda }\end{array}$ & Autosomalny dominujący & GP1BA (17p13.2) \\
\hline & Zespół Bernarda-Souliera & Autosomalny recesywny & $\begin{array}{l}\text { GP9 (3q21.3) } \\
\text { GP1BA (17p13.2) } \\
\text { GP1BB (22q11.21) }\end{array}$ \\
\hline & Trombastenia Glanzmanna & Autosomalny recesywny & $\begin{array}{l}\text { ITGA2B (17q21.32) } \\
\text { ITGB3(17q21.32) }\end{array}$ \\
\hline & $\begin{array}{l}\text { Defekt receptora } \\
\text { dla kolagenu }\end{array}$ & Autosomalny recesywny & GP6 (19q13.42) \\
\hline \multirow[t]{2}{*}{$\begin{array}{l}\text { Anomalie receptorów } \\
\text { dla rozpuszczalnych agonistów }\end{array}$} & $\begin{array}{l}\text { Defekt receptora } \\
\text { dla ADP }-\mathrm{P} 2 \mathrm{Y}_{12}\end{array}$ & Autosomalny recesywny & $P 2 Y 12(3 q 25.1)$ \\
\hline & $\begin{array}{l}\text { Defekt receptora } \\
\text { dla tromboksanu } A_{2}\end{array}$ & Autosomalny recesywny & TBXA2R (19p13.3) \\
\hline \multirow[t]{5}{*}{ Anomalie ziarnistości płytkowych } & $\begin{array}{l}\text { Zespół Hermansky'ego- } \\
\text {-Pudlaka }\end{array}$ & Autosomalny recesywny & $\begin{array}{l}\text { HPS1, AP3B1, HPS3-6, DT- } \\
- \text { NBP1, BLO1S3, BLOC1S6 } \\
(10 q 24.2,5 q 14.1,3 q 24, \\
22 q 12.1,11 p 14,10 q 24.32, \\
6 p 22.3,19 q 13.32, \\
15 q 21.1)\end{array}$ \\
\hline & Zespół Chediaka-Higashiego & Autosomalny recesywny & CHSI/LYST (1q42) \\
\hline & $\begin{array}{l}\text { Izolowany defekt } \\
\text { ziarnistości } \delta\end{array}$ & Autosomalny dominujący & Nieznany \\
\hline & Zespół szarych płytek & Autosomalny recesywny & NBEAL2 (3p21.31) \\
\hline & Skaza płytkowa Quebec & Autosomalny dominujący & PLAU (10q22.2) \\
\hline \multirow[t]{2}{*}{$\begin{array}{l}\text { Anomalie dróg przekazywania } \\
\text { sygnału }\end{array}$} & $\begin{array}{l}\text { Niedobór syntazy tromboksa- } \\
\text { nu (zespół Ghosal) }\end{array}$ & Autosomalny recesywny & TBXAS1 (7q34-q35) \\
\hline & $\begin{array}{l}\text { Niedobór cytozolowej fosfo- } \\
\text { lipazy } A_{2} \alpha\end{array}$ & Autosomalny recesywny & PLA2G4A (1q25) \\
\hline \multirow{2}{*}{$\begin{array}{l}\text { Zaburzenia prokoagulacyjnej } \\
\text { aktywności płytek }\end{array}$} & Zespół Scotta & Autosomalny recesywny & TMEM16F (12q12-13.11) \\
\hline & Zespół Stormorken & Autosomalny dominujący & STIM1 (11p15.4) \\
\hline
\end{tabular}

ADP (adenosine diphosphate) - adenozynodifosforan 


\section{Diagnostyka}

Wrodzone trombocytopatie należą do rzadkich przyczyn skaz krwotocznych i dlatego diagnostykę w ich kierunku należy przeprowadzać po wykluczeniu innych, częściej występujących, defektów hemostazy pierwotnej (nabyte małopłytkowości, choroba von Willebranda [VWD, von Willebrand disease], nabyte trombocytopatie) [4]. Kandydatem do badania w kierunku IPFD powinien być pacjent $z$ wywiadem skazy skórno-śluzówkowej lub z nadmiernymi krwawieniami po urazach lub zabiegach inwazyjnych (np. po ekstrakcji zęba), u którego na podstawie badania klinicznego i wstępnych badań hemostazy wykluczono inne przyczyny skazy krwotocznej. Prawdopodobieństwo rozpoznania IPFD jest większe u osób $z$ dodatnim wywiadem rodzinnym w kierunku skazy krwotocznej. Według ostatnio opublikowanych zaleceń SSC (Scientific and Standardization Committee)/ISTH (International Society on Thrombosis and Hemostasis) diagnostyka laboratoryjna IPFD powinna być poprzedzona badaniami wstępnymi, do których zaliczono: morfologię krwi z liczbą płytek, czas częściowej tromboplastyny po aktywacji (APTT, activated partial thromboplastin time), czas protrombinowy, antygen i aktywność czynnika von Willebranda (vWf, von Willebrand factor) i aktywność czynnika VIII [5]. Jeśli wyniki tych testów są prawidłowe, to należy wykonać badania diagnostyczne w kierunku IPFD, które podzielono na trzy etapy. Badania pierwszego etapu obejmują: 1) rozmaz krwi obwodowej ze zwróceniem szczególnej uwagi na wielkość i morfologię płytek, obecność nieprawidłowych ziarnistości i ciałek Döhle'a w leukocytach oraz cech dyserytropoezy, 2) optyczną agregację płytek $z$ pięcioma podstawowymi agonistami (epinefryna, adenozynodifosforan [ADP, adenosine diphospha$t e]$, kolagen, kwas arachidonowy i rystocetyna), 3) uwalnianie ziarnistości płytkowych za pomoca lumiagregometru i metodą immunoenzymatyczną (ELISA, enzyme-linked immunosorbent assay test), 4) oznaczenie głównych glikoprotein (GP) błony płytkowej metodą cytometrii przepływowej (Ib, Ib/IX, IIb/IIIa, IIIa). Umożliwiają one rozpoznanie najważniejszych i najczęstszych IPFD. Jeśli wymienione wyżej testy nie pozwolą na ustalenie rozpoznania, to należy przejść do drugiego etapu diagnostyki. W jej skład wchodzą: oznaczenie agregacji płytek $z$ rozszerzonym panelem agonistów i cytometrii przepływowej $z$ dodatkowymi przeciwciałami, badanie liczby i struktury ziarnistości płytkowych $\mathrm{w}$ transmisyjnym mikroskopie elektronowym, oznaczenie zawartości ziarnistości płytkowych me- todą ELISA, luminometrii i immunofluorescencji, badanie retrakcji skrzepu, oznaczenie tromboksanu $\mathrm{B}_{2}\left(\mathrm{TxB}_{2}\right.$, thromboxane $\left.\mathrm{B}_{2}\right) \mathrm{w}$ supernatancie surowicy metodą ELISA lub radioimmunologiczną (RIA, radioimmunoassay). U osób, u których nadal nie udało się dokonać rozpoznania, a istnieje duże prawdopodobieństwo kliniczne obecności IPFD, wykonuje się badania trzeciego etapu — przede wszystkim molekularne badania genetyczne.

\section{Zespół Bernarda-Souliera}

Zespół Bernarda-Souliera to wrodzona skaza krwotoczna charakteryzująca się małopłytkowością $z$ dużymi płytkami, przedłużonym czasem krwawienia i brakiem aglutynacji płytek indukowanej rystocetyną. Dziedziczy się ją jako cechę autosomalną recesywną. Częstość występowania BSS szacuje się na mniej niż 1:1 000000 [6].

Przyczyną BSS jest brak ekspresji kompleksu GPIb/IX/V na powierzchni płytek krwi lub zmniejszona ekspresja tego kompleksu, który jest receptorem dla vWf. Jego defekt odpowiada za zmniejszone wiązanie vWf do błony płytki i upośledzenie adhezji. Mutacje odpowiedzialne za BSS mogą dotyczyć genów dla GPIb $\alpha, \operatorname{GPIb} \beta$ i GPIX, natomiast nie obserwowano w tej chorobie mutacji genu dla GPV (tab. 1). Na modelu mysim wykazano zaburzenia megakariopoezy i tworzenia propłytek, co może się przyczyniać do makrotrombocytopenii. Skaza krwotoczna może mieć ciężki przebieg kliniczny. Krwawienia $z$ nosa, dziąseł, sińce pojawiają się już w pierwszych latach życia. Mogą również występować krwawienia $z$ przewodu pokarmowego. U kobiet głównym problemem są krwotoczne miesiączki i krwawienia okołoporodowe. Niebezpieczne są krwawienia pourazowe [7].

Czas krwawienia i czas okluzji w aparacie PFA-100 (CT PFA, closure time PFA) z wkładami kolagenu/ADP i kolagenu/epinefryny są przedłużone. Liczba płytek pozostaje obniżona i zawiera się zwykle w przedziale $20-140 \mathrm{G} / \mathrm{l}$. W rozmazie krwi obwodowej stwierdza się duże płytki, z których część może mieć średnicę większą od erytrocytu. Charakterystyczny jest brak aglutynacji płytek indukowanej rystocetyną, który nie ulega korekcji po dodaniu prawidłowego osocza (tab. 2). Agregacja płytek $z$ fizjologicznymi agonistami jest prawidłowa. Szczególowe rozpoznanie można ustalić na podstawie oceny gęstości GPIb $\alpha$ na powierzchni płytek krwi metodą cytometrii przepływowej i przez wykrycie defektów w genach kodujących podjednostki GPIb/IX/V metodami biologii molekularnej. W różnicowaniu należy uwzględnić vWD, GT oraz makrotrombocytopenie wrodzone, 
Tabela 2. Różnicowanie wrodzonych trombocytopatii na podstawie liczby płytek i wyników agregacji

Table 2. Differentiating of inherited platelet function disorders according to platelet count and results of platelet aggregation

\begin{tabular}{|l|l|l|}
\hline Trombocytopatia & Liczba płytek & Wynik agregacji płytek \\
\hline Zespół Bernarda-Souliera & Obniżona & Brak aglutynacji z rystocetyną \\
\hline Płytkowy typ choroby von Willebranda & Obniżona & $\begin{array}{l}\text { Zwiększona aglutynacja pod wpływem małych } \\
\text { stęźen rystocetyny }\end{array}$ \\
\hline Trombastenia Glanzmanna & Prawidłowa & $\begin{array}{l}\text { Brak agregacji ze wszystkimi agonistami } \\
\text { Prawidłowa aglutynacja z rystocetyną }\end{array}$ \\
\hline Defekt GPVI & Prawidłowa & Upośledzona odpowiedź na kolagen i konwulksynę \\
\hline Defekty P2Y 12 & Prawidłowa & Upośledzona odpowiedź na ADP \\
\hline Defekt receptora dla TxA 2 & Prawidłowa & $\begin{array}{l}\text { Brak odpowiedzi na kwas arachidonowy } \\
\text { Upośledzona odpowiedź na innych agonistów }\end{array}$ \\
\hline Defekt ziarnistości gęstych & Prawidłowa & $\begin{array}{l}\text { Brak/upośledzona odpowiedź na niskie stężenia } \\
\text { kolagenu } \\
\text { Agregacja jednofazowa po ADP i epinefrynie }\end{array}$ \\
\hline $\begin{array}{l}\text { Zespół szarych płytek } \\
\text { Skaza płytkowa Quebec }\end{array}$ & Obniżona & $\begin{array}{l}\text { Najczęściej prawidłowa lub upośledzona odpowiedź } \\
\text { na agonistę PAR-1 }\end{array}$ \\
\hline Zespół Ghosal & Prawidłowa lub obniżona & Upośledzona odpowiedź na epinefrynę \\
\hline Niedobór fosfolipazy A $\mathrm{A}_{2}$ & Prawidłowa lub obniżona & Upośledzona odpowiedź na kwas arachidonowy \\
\hline Zespół Scotta & Prawidłowa & Upośledzona odpowiedź na ADP i kolagen \\
\hline Zespół Stormorken & Prawidłowa & Prawidłowa \\
\hline wowany proteazą 1 & Obniżona & Prawidłowa \\
\hline
\end{tabular}

takie jak małopłytkowość związana z mutacją genu MYH9, zespół szarych płytek (GPS, gray platelet syndrome) i płytkowy typ vWD.

\section{Trombastenia Glanzmanna}

Trombastenia Glanzmanna jest rzadko występującą skazą płytkową związaną $z$ wrodzonym, ilościowym lub jakościowym, defektem płytkowej integryny $\alpha \operatorname{IIb} \beta_{3}$ (GPIIb/IIIa), która jest receptorem dla fibrynogenu (może również wiązać inne ligandy — vWf, fibronektynę, trombospondynę). Dziedziczy się w sposób autosomalny recesywny. Częstość występowania GT jest prawdopodobnie mniejsza niż 1 na 1000000 mieszkańców.

Geny dla GP $\alpha$ IIb i GP $\beta_{3}$ (ITGA2B, ITGB3) znajdują się obok siebie na długim ramieniu chromosomu 17 (17q21-23). Dotychczas opisano ponad 100 mutacji genów ITGA2B i ITGB3 odpowiedzialnych za wystąpienie GT (http://med.mssm.edu/ /glanzmanndb). Prowadzą one do ilościowego lub, rzadziej, jakościowego defektu integryny $\alpha \operatorname{IIb} \beta_{3}$. Zależnie od rodzaju defektu i ekspresji resztkowej integryny na błonie płytkowej wyróżnia się trzy typy GT:

- $\quad$ typ I - poniżej 5\% resztkowej $\alpha \operatorname{IIb} \beta_{3}$;

- $\quad$ typ II - 5-20\% $\alpha \operatorname{IIb} \beta_{3}$;

- wariant GT - defekt jakościowy $\alpha \operatorname{IIb} \beta_{3}$.
Nie stwierdzono istotnej korelacji między przebiegiem klinicznym skazy krwotocznej a fenotypem cytometrycznym choroby [8]. Skaza krwotoczna ma przebieg umiarkowany lub ciężki. U większości chorych ujawnia się przed 5. rokiem życia, często już w okresie noworodkowym. Najczęściej objawia się wybroczynami i sińcami, krwawieniem $z$ dziąseł, $z$ nosa i krwotocznymi miesiączkami. Mogą również występować krwawienia $z$ przewodu pokarmowego i krwiomocz. Krwawienia $z$ nosa są najczęstszą przyczyną ciężkich krwawień wymagających przetoczenia krwi. Powtarzające się krwawienia mogą prowadzić do niedokrwistości $z$ niedoboru żelaza, zwłaszcza u dzieci. Urazy oraz procedury inwazyjne i zabiegi chirurgiczne przeprowadzane bez odpowiedniego przygotowania mogą być powodem krwawień niebezpiecznych dla życia [9].

Trombastenia Glanzmanna charakteryzuje się przedłużonym czasem krwawienia i CT PFA $z$ kolagenem/epinefryną i kolagenem/ADP, prawidłową liczbą i wielkością płytek, upośledzoną retrakcją skrzepu i zaburzoną agregacją płytek krwi. Płytki pacjentów z GT nie agregują pod wpływem ADP, kolagenu, trombiny, epinefryny ani kwasu arachidonowego, natomiast ulegają aglutynacji w obecności rystocetyny. O rozpoznaniu decyduje wykazanie 
braku lub zmniejszonej ekspresji $\alpha \operatorname{IIb} \beta_{3}$ na płytkach krwi metodą cytometrii przepływowej. U osób $z$ wariantem GT ekspresja $\alpha \operatorname{IIb} \beta_{3}$ pozostaje prawidłowa, natomiast upośledzone jest wiązanie przez stymulowane płytki przeciwciała monoklonalnego 1 (PAC-1, platelets monoclonal antibody 1 ) specyficznego dla aktywowanej $\alpha \operatorname{IIb} \beta_{3}$ lub znakowanego fluorochromem fibrynogenu. Ostatnim etapem rozpoznania GT powinno być badanie molekularne w celu ustalenia mutacji sprawczej [10].

\section{Płytkowy typ choroby von Willebranda}

Do tej pory opisano około 50 przypadków. Płytkowy typ choroby von Willebranda (inaczej „rzekoma choroba von Willebranda”) charakteryzuje się spontanicznym wiązaniem osoczowego vWf do płytek krwi. Odpowiada za to mutacja genu dla GPIba (GPIBA) znajdującego się na chromosomie 17 , w której wyniku konformacyjne zmiany GPIb $\alpha$ umożliwiają bezpośrednie wiązanie vWf. Przyspieszone usuwanie $z$ krążenia dużych multimerów vWf (HMWMvWf, high molecular weight multimers $v W F$ ) i blokowanie GPIb są przyczyną skazy krwotocznej. Chorobę dziedziczy się w sposób autosomalny dominujący. Objawy kliniczne i laboratoryjne przypominają vWD typu 2B [11].

Spośród odchyleń od normy w badaniach laboratoryjnych stwierdza się: łagodną małopłytkowość, makrocytozę płytek, tendencję do występowania skupień płytek w rozmazie krwi, przedłużony czas krwawienia i CT PFA, zmniejszenie zawartości HMWMvWf w osoczu, prawidłową lub zmniejszoną aktywnośćczynnika VIII. Podobniejak wvWD typu2B podstawą rozpoznania jest zwiększona aglutynacja płytek pod wpływem małych stężeń rystocetyny (LD-RIPA, low dose ristocetin-induced platelet agglutination). Różnicowanie płytkowego typu vWD i typu 2B vWD umożliwia przeprowadzenie testu LD-RIPA z użyciem płytek od zdrowego dawcy. Prawidłowe płytki zawieszone w osoczu pacjenta $z$ płytkowym typem vWD nie ulegają zwiększonej aglutynacji pod wplywem małych stężeń rystocetyny [12]. Jedynym pewnym testem diagnostycznym jest wykazanie specyficznej mutacji genu GPIBA.

\section{Zaburzenia ziarnistości gęstych $(\delta)$}

Ziarnistości $\delta$ należą do organelli komórkowych, które występują w megakariocytach i płytkach krwi. Są w nich magazynowane między innymi: adenozynotrifosforan (ATP, adenosine triphosphate), ADP, jony wapnia, serotonina, fosfoinozytole. Defekt ziarnistości gęstych może być izolowany lub współwystępować $z$ innymi anomaliami [13].
Izolowany defekt ziarnistości gęstych dotyczy prawdopodobnie stosunkowo dużego odsetka osób $z$ łagodną skazą krwotoczną o nieznanej przyczynie, ale większość przypadków pozostaje nierozpoznana. Podłoże genetyczne nie jest do tej pory wyjaśnione. Zróżnicowany przebieg kliniczny — od przypadków bezobjawowych, poprzez łagodną, do umiarkowanej skazy krwotocznej - i znaczne różnice w wynikach agregacji płytek wskazują, że ta trombocytopatia jest zespołem defektów ziarnistości gęstych o różnych patomechanizmach [14].

\section{Zespół Hermansky'ego-Pudlaka}

Zespół Hermansky'ego-Pudlaka (HPS, Hermansky-Pudlak syndrome) może być wywołany przez mutacje różnych genów (tab. 2). Wyróżnia się dziewięć podtypów (HPS1-HPS9), których wspólnymi cechami są zaburzenia czynności płytek związane $z$ nieprawidłowymi ziarnistościami $\delta$ i bielactwo skórno-oczne. Chorobę dziedziczy się w sposób autosomalny i recesywny. Choć należy do bardzo rzadkich IPFD, to jest najczęstszą genetycznie uwarunkowaną chorobą w Puerto Rico (1:800 mieszkańców). Inne, poza łagodną skazą krwotoczną, objawy kliniczne zależą od mutacji specyficznego genu. Mutacje HPS1 i HPS4 są odpowiedzialne za zwłóknienie płuc, a mutacja AP3B1 (podtyp HPS2) — za neutropenię i niedobór odporności [14].

\section{Zespół Chédiaka-Higashiego}

Zespół Chédiaka-Higashiego (CHS, Chédiak-Higashi syndrome) charakteryzuje się defektem ziarnistości gęstych, oczno-skórnym bielactwem i zaburzeniami odporności. Dziedziczy się w sposób autosomalny i recesywny. Jest związany $z$ mutacją genu $C H S$ zlokalizowanego na chromosomie 1q43. W jej wyniku dochodzi do produkcji nieprawidłowego białka LYST, które reguluje transport ziarnistości $\delta$, melanosomów i lizosomów [14]. Skaza krwotoczna skórno-śluzówkowa ma łagodny lub umiarkowany przebieg. Typowe są częste infekcje, najczęściej wywołane przez gronkowca złocistego i paciorkowce. Do wczesnych objawów klinicznych należą neuropatie ośrodkowe i obwodowe, drgawki i objawy zwyrodnienia rdzeniowo-móżdżkowego związane $z$ limfo-histiocytarnymi naciekami układu nerwowego. Dzieci chore na CHS najczęściej umierają w 1. dekadzie życia wskutek infekcji lub limfoproliferacji.

Podstawą laboratoryjnego rozpoznania CHS jest wykrycie peroksydazo-dodatnich ziarnistości w neutrofilach, jak również w innych komórkach. Ponadto u chorych stwierdza się zaburzenia 
agregacji płytek (brak drugiej fazy agregacji), zwiększenie stosunku ATP do ADP i zmniejszony wychwyt serotoniny.

\section{Zespół szarych płytek}

Zespół szarych płytek jest wrodzonym defektem ziarnistości $\alpha$. Płytki pozbawione ziarnistości $\alpha$ uwidaczniają się w rozmazie krwi jako szare i bezziarniste, a jednocześnie są duże i zniekształcone. Defekt dziedziczy się autosomalnie recesywnie. Zespół ten występuje niezwykle rzadko; w literaturze medycznej opisano około 100 przypadków.

Zaburzenia czynności płytek są związane $z$ brakiem lub zmniejszeniem liczby ziarnistości $\alpha$ i substancji $\mathrm{w}$ nich magazynowanych: czynnika płytkowego 4 , $\beta$-tromboglobuliny, vWf, płytkopochodnego czynnika wzrostu (PDGF, platelet-derived growth factor), transformującego czynnika wzrostu $\beta_{1}$ (TGF- $\beta_{1}$, transforming growth factor $\beta_{1}$ ), czynnika V, fibrynogenu, immunoglobuliny $\mathrm{G}$ (IgG). Odpowiada za to mutacja w genie kodującym białko NBEAL2, które bierze udział w biogenezie ziarnistości $\delta \mathrm{w}$ megakariocytach [15]. Defekt magazynowania PDGF i TGF- $\beta_{1}$ może prowadzić do ich stałego uwalniania $z$ megakariocytów do szpiku i w konsekwencji — do jego zwłóknienia.

Skaza krwotoczna skórno-śluzówkowa jest umiarkowana lub łagodna. Niebezpieczne mogą być krwawienia pourazowe. U większości chorych stwierdza się powiększenie śledziony związane ze zwłóknieniem szpiku [16].

Za rozpoznaniem GPS przemawia obecność w rozmazie krwi barwionym metodą May-Grünwalda-Giemsy szarych, zniekształconych, dużych płytek. Liczba płytek jest zwykle zmniejszona w różnym stopniu. Agregacja płytek najczęściej pozostaje prawidłowa, ale może być upośledzona $z$ jednym lub większą liczbą agonistów. Rozpoznanie GPS potwierdza brak lub zmniejszone stężenie w płytkach $\beta$-tromboglobuliny, czynnika płytkowego 4, fibrynogenu, vWf, czynnika V, PDGF oraz brak lub zmniejszenie liczby ziarnistości $\alpha$ w plytkach badanych w mikroskopie elektronowym.

\section{Skaza płytkowa Quebec}

Skaza płytkowa Quebec charakteryzuje się zwiększoną zawartością urokinazowego aktywatora plazminogenu (u-PA, urokinase plasminogen activator) $\mathrm{w}$ płytkach krwi i wtórnymi zmianami białek magazynowanych w ziarnistościach $\alpha$. Dziedziczenie jest autosomalne i dominujące. Defekt ten rozpoznano u około 40 mieszkańców prowincji Quebec w Kanadzie. Dotychczas nie wykryto tej choroby w innych regionach świata.
Zwiększona ekspresja u-PA w megakariocytach jest związana $\mathrm{z}$ tandemową duplikacją genu PLAU [13]. Jest ona odpowiedzialna za wewnątrzpłytkową generację plazminy i proteolityczną degradację białek magazynowanych w ziarnistościach $\alpha$, w tym czynnika V. Przyczyną skazy krwotocznej jest zwiększona aktywność fibrynolityczna w miejscu uszkodzenia ściany naczynia, zależna od uwalniania dużych ilości u-PA w czasie aktywacji płytek. W skazie płytkowej Quebec zaburzony jest również proces krzepnięcia krwi w związku $z$ upośledzonym tworzeniem kompleksu protrombinazy na tle niedoboru płytkowego czynnika V.

W odróżnieniu od innych IPFD objawy kliniczne przypominają skazę osoczową. U około $50 \%$ chorych występują krwawienia dostawowe prowadzące do artropatii hemofilowej. Niebezpieczne są opóźnione krwawienia po urazach i zabiegach operacyjnych. Opisano również 3 przypadki śmiertelnych krwawień śródczaszkowych. Charakterystyczne są duże wylewy podskórne. Do innych objawów należą krwiomocz, krwawienia $z$ nosa, przedłużone krwawienia miesiączkowe i opóźnione gojenie ran [17].

Liczba płytek jest prawidłowa lub umiarkowanie zmniejszona (80-245 G/1). Charakterystyczny jest brak agregacji płytek indukowanej małymi dawkami epinefryny. Ostateczne rozpoznanie można ustalić, stwierdzając zwiększoną zawartość u-PA w płytkach krwi metodą ELISA lub Western blot. Metodą Western blot można wykazać również degradację białek ziarnistości fibrynogenu, vWf, trombospondyny 1 , osteonektyny, fibronektyny czy P-selektyny. Prostą metodą, która może służyć do wykluczenia rozpoznania skazy płytkowej Quebec, jest jednoczesne oznaczenie produktów degradacji fibrynogenu (FDP, fibryn degradation products) w surowicy i dimeru D w osoczu. U osób $z$ tą chorobą stężenie FDP w surowicy pozostaje zwiększone przy prawidłowych wartościach dimeru D w osoczu [18].

\section{Defekt receptora dla kolagenu}

Opisano 6 chorych $z$ dwoma różnymi mutacjami genu GP6 odpowiedzialnymi za zmniejszoną ekspresję i/lub funkcję GPVI. U wszystkich pacjentów występowały objawy łagodnej skazy krwotocznej skórno-śluzówkowej. Defekt GPVI charakteryzuje się brakiem agregacji płytek pod wpływem kolagenu i konwulksyny [19].

\section{Defekt receptora dla $\mathrm{TxA}_{2}$}

Przyczyną łagodnej skazy krwotocznej jest mutacja genu kodującego receptor dla $\mathrm{TxA}_{2}$ przy 
zachowanej zdolności do syntezy tego związku. Charakteryzuje się upośledzeniem agregacji płytek indukowanej kwasem arachidonowym. Odpowiedź płytek na inne induktory agregacji jest zróżnicowana - może występować zmniejszenie pierwotnej lub brak wtórnej fali agregacji [20].

\section{Defekt receptora dla ADP}

Adenozynodifosforan aktywuje płytki za pomocą dwóch specyficznych receptorów - $\mathrm{P}_{1} \mathrm{Y}_{1}$ i $\mathrm{P}_{12}$. Wrodzone defekty receptora $\mathrm{P}_{12} \mathrm{Y}_{12}$ opisano u 7 niespokrewnionych chorych. Trombocytopatię dziedziczy się w sposób autosomalny i recesywny. U osób obarczonych tym defektem występuje lagodna lub umiarkowana skaza krwotoczna. Charakterystyczny jest brak lub zmniejszenie agregacji płytek z ADP. Uważa się, że defekt $\mathrm{P}_{2} \mathrm{Y}_{12}$ może częściej występować, lecz nie jest rozpoznawany. Testem diagnostycznym jest badanie hamowania aktywności stymulowanej prostaglandyną E1 płytkowej cyklazy adenylowej przez ADP [21]. Dotychczas nie opisano wrodzonych zaburzeń receptora $\mathrm{P}_{2} \mathrm{Y}_{1}$.

\section{Anomalie dróg przekazywania sygnału w płytkach}

Opisano wiele różnych defektów związanych $\mathrm{z}$ anomaliami przekazywania sygnału w płytkach, takich jak: zaburzenia aktywacji fosfolipazy C, niedobory syntazy tromboksanu lub cyklooksygenazy, defekty kaskady białka G i inne. Prowadzą one do zaburzenia sekrecji substancji zawartych w płytkach i upośledzenia agregacji płytek. Klinicznie mogą się objawiać łagodną skazą krwotoczną skórno-śluzówkową. Ostatnio odkryto dwie specyficzne mutacje odpowiedzialne za defekty syntazy tromboksanu (zespół Ghosal) i fosfolipazy $\mathrm{A}_{2}$ (tab. 1) [13].

\section{Zespół Scotta}

Zespół Scotta to niezwykle rzadko występująca skaza krwotoczna charakteryzująca się zmniejszoną zdolnością płytek krwi do tworzenia na ich powierzchni kompleksów tenazy i protrombinazy. Dziedziczy się autosomalnie recesywnie. Przyczyną choroby jest mutacja genu TMEM16F kodującego przezbłonowe białko 16F, która prowadzi do zaburzenia transportu fosfatydyloseryny do zewnętrznej warstwy błony komórek krwi i upośledzenia tworzenia mikrocząstek płytkowych (tab. 1). Skaza krwotoczna ma łagodny lub umiarkowany przebieg. Opisano ciężkie krwawienie poporodowe oraz nadmierne krwawienia po ekstrakcjach zębów. Czas krwawienia oraz liczba, wielkość i agregacja płytek krwi są prawidłowe, natomiast upośledzo- ne jest zużycie protrombiny. Rozpoznanie można ustalić, badając w cytometrii przepływowej ekspresję fosfatydyloseryny i generację mikrocząstek płytkowych [22].

\section{Zespól Stormorken}

Płytki krwi w zespole Stormorken, rzadkiej skazie krwotocznej, wykazują stałą, spoczynkową aktywność prokoagulacyjną wyrażającą się ekspresją fosfatydyloseryny i zwiększoną generacją mikrocząstek. Trombocytopatii towarzyszą małopłytkowość, łagodna niedokrwistość, asplenia oraz bóle głowy, zwężenie źrenic i rybia łuska. Zespół jest spowodowany mutacją genu STIM1 [13, 23].

\section{Wrodzone małopłytkowości \\ z towarzyszącymi zaburzeniami czynności płytek}

Wrodzone małopłytkowości z towarzyszącymi zaburzeniami czynności płytek to grupa chorób lub zespołów chorobowych (zespół Wiskotta-Aldricha, makrotrombocytopenia sprzężona $z$ chromosomem X, zaburzenia związane z mutacją genu $M Y H 9$ $\mathrm{i}$ in.) charakteryzujących się dominującą małopłytkowością, której towarzyszą łagodne zaburzenia czynności płytek, a często również inne objawy kliniczne. Zostaną one szczegółowo omówione w przygotowywanej do druku pracy poświęconej małopłytkowościom wrodzonym.

\section{Leczenie}

Zależnie od rodzaju i ciężkości defektu płytek oraz objawów klinicznych stosuje się różne metody leczenia. Krwawienia $z$ nosa i śluzówek jamy ustnej udaje się zwykle zahamować lekami antyfibrynolitycznymi i/lub miejscowymi środkami hemostatycznymi (spongostan, tamponada, kwas traneksamowy do płukania jamy ustnej). W przypadku braku skuteczności tej metody leczenia u pacjentów $z$ ciężkimi defektami płytek (GT, BSS) należy przetoczyć koncentrat krwinek płytkowych (kkp), który jest podstawowym lekiem stosowanym w krwawieniach zagrażających życiu u chorych na IPFD. Jedynym wyjątkiem są krwawienia w skazie płytkowej Quebec, które odpowiadają na leki antyfibrynolityczne, a przetoczenia kkp są w ich przypadku nieskuteczne. W powstrzymywaniu krwotocznych miesiączek skuteczne są leki hormonalne i/lub leki antyfibrynolityczne.

Głównym problemem u chorych na IPFD jest zapewnienie hemostazy w czasie inwazyjnych procedur, zabiegów operacyjnych, porodu i w innych krwawieniach pourazowych. Pacjenci z ciężkimi 
defektami płytek wymagają zwykle przygotowania do zabiegu za pomocą kkp, podczas gdy w większości łagodnych przypadków IPFD wystarczy stosowanie desmopresyny. U chorych na GT opornych na przetoczenia kkp $z$ powodu alloimunizacji lekiem $z$ wyboru w ciężkich krwawieniach i w celu osłony inwazyjnych zabiegów jest rekombinowany aktywny czynnik VII $[24,25]$. Jest on również skutecznym lekiem przeciwkrwotocznym u chorych na BSS, $z$ przeciwciałami przeciwpłytkowymi, ale dotychczas nie uzyskał rejestracji do leczenia tej skazy krwotocznej. Przeszczepienie allogenicznych krwiotwórczych komórek macierzystych można rozważyć $u$ chorych na GT i BSS $z$ nawracającymi, zagrażającymi życiu krwawieniami, którzy mają zgodnego dawcę rodzinnego [26]. Zaleca się stosowanie zredukowanego kondycjonowania.

Zapobieganie krwawieniom polega na edukacji pacjentów, niestosowaniu niesteroidowych leków przeciwzapalnych, zwłaszcza kwasu acetylosalicylowego (ASA, acetylsalicylic acid) u osób z ciężkimi IPFD, unikaniu urazów, dbaniu o higienę jamy ustnej z częstą kontrolą stomatologiczną oraz kontroli krwawień miesiączkowych za pomocą leków hormonalnych.

\section{Piśmiennictwo}

1. Hayward C.P., Rao A.K., Cattaneo M. Congenital platelet disorders: overview of their mechanisms, diagnostic evaluation and treatment. Haemophilia 2006; 12 (supl. 3): 128-136.

2. Ahmad F., Kannan M., Ranjan R. i wsp. Inherited platelet function disorders versus other inherited bleeding disorders: an Indian overview. Thromb. Res. 2008; 121: 835-841.

3. Leo V.C., Morgan N.V., Bem D. i wsp.; UK GAPP Study Group. Use of next-generation sequencing and candidate gene analysis to identify underlying defects in patients with inherited platelet function disorders. J. Thromb. Haemost. 2015; 13: 643-650.

4. Israels S.J., El-Ekiaby M., Quiroga T., Mezzano D. Inherited disorders of platelet function and challenges to diagnosis of mucocutaneous bleeding. Haemophilia 2010; 16 (supl. 5): 152-159.

5. Gresele P.; Subcommittee on Platelet Physiology of the International Society on Thrombosis and Hemostasis. Diagnosis of inherited platelet function disorders: guidance from the SSC of the ISTH. J. Thromb. Haemost. 2015; 13: 314-322.

6. López J.A., Andrews R.K., Afshar-Kharghan V., Berndt M.C. Bernard-Soulier syndrome. Blood 1998; 91: 4397-4418.

7. Andrews R., Berndt M. Bernard-Soulier syndrome: an update. Semin. Thromb. Hemost. 2013; 39: 656-662.

8. Farsinejad A., Abolghasemi H., Kazemi A. i wsp. Classification of Iranian patients with Glanzmann's thrombasthenia using a flow cytometric method. Platelets 2011; 22: 321-327.
9. Solh T., Botsford A., Solh M. Glanzmann's thrombasthenia: pathogenesis, diagnosis, and current and emerging treatment options. J. Blood Med. 2015; 6: 219-227.

10. Nurden A.T., Pillois X., Wilcox D.A. Glanzmann thrombasthenia: state of the art and future directions. Semin. Thromb. Hemost. 2013; 39: 642-655.

11. Othman M. Platelet-type von Willebrand disease: a rare, often misdiagnosed and underdiagnosed bleeding disorder. Semin. Thromb. Hemost. 2011; 37: 464-469.

12. Enayat M.S., Guilliatt A.M., Lester W. i wsp. Distinguishing between type $2 \mathrm{~B}$ and pseudo-von Willebrand disease and its clinical importance. Br. J. Haematol. 2006; 133: 664-666.

13. Nurden A.T., Nurden P. Congenital platelet disorders and understanding of platelet function. Br. J. Haematol. 2014; 165: 165-178.

14. Masliah-Planchon J., Darnige L., Bellucci S. Molecular determinants of platelet delta storage pool deficiencies: an update. $\mathrm{Br}$. J. Haematol. 2013; 160: 5-11.

15. Bottega R., Pecci A., De Candia E. i wsp. Correlation between platelet phenotype and NBEAL2 genotype in patients with congenital thrombocytopenia and -granule deficiency. Haematologica 2013; 98: 868-874.

16. Nurden A.T., Nurden P. The gray platelet syndrome: clinical spectrum of the disease. Blood Rev. 2007; 21: 21-36.

17. Hayward C.P., Rivard G.E. Quebec platelet disorder. Expert Rev. Hematol. 2011; 4: 137-141.

18. Blavignac J., Bunimov N., Rivard G.E., Hayward C.P. Quebec platelet disorder: update on pathogenesis, diagnosis, and treatment. Semin. Thromb. Hemost. 2011; 37: 713-720.

19. Matus V., Valenzuela G., Sáez C.G. An adenine insertion in exon 6 of human GP6 generates a truncated protein associated with a bleeding disorder in four Chilean families. J. Thromb. Haemost. 2013; 11: 1751-1759.

20. Watson S.P., Lowe G.C., Lordkipanidzé M., Morgan N.V. and GAPP consortium. Genotyping and phenotyping of platelet function disorders. J. Thromb. Haemost. 2013; 11 (supl. 1): 351-363.

21. Cattaneo M. The platelet $\mathrm{P} 2 \mathrm{Y}_{12}$ receptor for adenosine diphosphate: congenital and drug-induced defects. Blood 2011; 117: 2102-2112.

22. Halliez M., Fouassier M., Robillard N. i wsp. Detection of phosphatidyl serine on activated platelets' surface by flow cytometry in whole blood: a simpler test for the diagnosis of Scott syndrome. Br. J. Haematol. 2015 Mar 31 [złożone do druku].

23. Misceo D., Holmgren A., Louch W.E. i wsp. A dominant STIM1 mutation causes Stormorken syndrome. Hum. Mutat. 2014; 35: $556-564$.

24. Di Minno G., Zotz R.B., d'Oiron R.; Glanzmann Thrombasthenia Registry Investigators. The international, prospective Glanzmann Thrombasthenia Registry: treatment modalities and outcomes of non-surgical bleeding episodes in patients with Glanzmann thrombasthenia. Haematologica 2015; 100: 1031-1037.

25. Poon M.C., d'Oiron R., Zotz R.B.; Glanzmann Thrombasthenia Registry Investigators. The international, prospective Glanzmann Thrombasthenia Registry: treatment and outcomes in surgical intervention. Haematologica 2015; 100: 1038-1044.

26. Wiegering V., Sauer K., Winkler B., Eyrich M., Schlegel P.G. Indication for allogeneic stem cell transplantation in Glanzmann's thrombasthenia. Hamostaseologie 2013; 33: 305-312. 